\title{
Trickling Filter for High Efficiency Treatment of Dairy Sewage
}

\author{
Radosław Żyłka', Wojciech Dąbrowski ${ }^{*}$, Elena Gogina², Olga Yancen² \\ 1 Bialystok University of Technology, Faculty of Building and Environmental Engineering, ul. Wiejska 45E, \\ 15-351 Białystok, Poland \\ 2 Moscow State University of Civil Engineering, Yaroslawskoyoe Shosse, Moscow, Russia \\ * Corresponding author's e-mail: dabrow@pb.edu.pl
}

\begin{abstract}
The article presents the results of the research on the possibility of using a trickling filter for high efficiency treatment of dairy sewage. Nowadays, to the best of the authors' knowledge, it is possible to change the activated sludge system to the trickling filter technology, especially in small dairy plants with lower raw sewage parameters in comparison to larger plants. In the research, dairy wastewater after dissolved air flotation (DAF) process was treated with a laboratory scale Gunt CE701e research model which allows to control the basic parameters of the treatment with a trickling filter (TF). The conducted study included determining the changing sewage parameters during the DAF process, as well as the trickling filter (TF) efficiency. Such parameters as Biological Oxygen Demand (BOD), Chemical Oxygen Demand (COD), total Organic Carbon (TOC), total Kjeldahl nitrogen (TKN) and total phosphorous (TP) were checked. The research results confirmed the possibility of high efficiency treatment of dairy sewage with DAF and trickling filter technologies. The average efficiency of DAF treatment was 59.3\% for BOD, $49.0 \%$ for COD and $80.0 \%$ for TP, while the average treatment efficiency of TF was $87.3 \%, 78.3 \%$ and $27.9 \%$ without recirculation and $95.2 \%, 85.5 \%$ and $42.0 \%$ with $100 \%$ recirculation applied, respectively. The load of TF during the operation without recirculation was on average $0.22 \mathrm{kgBOD} \cdot \mathrm{m}^{-3} \cdot \mathrm{d}^{-1}$ and 0.25 with $100 \%$ recirculation. Applying recirculation allowed to reach the BOD, COD and total phosphorus standards for the sewage discharged to a receiver from Bielmlek dairy WWTP. On the other hand, the concentration of total nitrogen exceeded the permitted standards in this facility.
\end{abstract}

Keywords: dairy sewage, trickling filter, dissolved air flotation, efficiency

\section{INTRODUCTION}

TFs have been used to provide biological sewage treatment for more than 100 years. A TF is a non-submerged fixed-film biological reactor using rock or plastic media over which sewage is distributed continuously [Tchobanoglous, 1997; Godoy-Olmos et al., 2016]. They were commonly used in Poland in the 1970s and 1980s for treating both municipal and food industry sewage. Classic TFs (sprinkling system) generally operated with Imhoff tanks. Additionally, rotary biological contactors (RBC) were widely applied in small towns and such facilities as hotels, holiday resorts etc. Discontinuing their usage in Poland resulted from introducing the demands concerning intensive removal of biogenic compounds in 1991 [Regulations, 1991; Regulations, 2014].
It practically caused the disappearance of this technology for the sake othe f activated sludge. In Russia, for example, a limited use of trickling filter stemmed from very high standards for removing the organic substance for specific sewage receivers. [Gogina \& Yantsen, 2015]. Unlike in Poland, wastewater treatment plants using TF or RBCs still function successfully, for instance in Great Britain, where RBCs operate with vertical or horizontal flow constructed wetlands [Obarska-Pempkowiak et al., 2010]. The experiments involving RBCs for landfill leachate treatment confirm that an effective usage of constructed wetlands technology is possible not only for the treatment of municipal sewage [Passeggi et al., 2012, Habte \& Eckstadt, 2013]. This technology, contrary to the activated sludge, is much simpler and bears lower exploitation cost. Operating TFs 
or RBCs do not generate the waste typical for the activated sludge method; they are also characterized by lower power requirements [EPA, 2000; Daigger \& Boltz, 2011; Post \& Medlock, 2002, Henrich \& Marggraff, 2013]. TFs can be classified as raughing, carbon oxidation, carbon oxidation and nitrification and tertiary nitrification [Tchobanoglous, 1997, Daigger \& Boltz 2011, Henrich, 2014]. The classification of TFs into low, medium and highly loaded ones is based on the value of $\mathrm{kgBOD}_{5} \cdot \mathrm{m}^{-3} \cdot \mathrm{d}^{-1}$ indicator. Highly loaded ones operate with $0.65-3.2 \mathrm{~kg} \mathrm{BOD} \cdot \mathrm{m}^{-}$ ${ }^{3} \cdot \mathrm{d}^{-1}$ and low loaded ones with 0.07 to $0.22 \mathrm{~kg}$ $\mathrm{BOD}_{5} \cdot \mathrm{m}^{-3} \cdot \mathrm{d}^{-1}$ [Tchobanoglous, 1997]. In the TFs classification, surface hydraulic load parameter, expressed as $\mathrm{m}^{3} \cdot \mathrm{m}^{-2} \cdot \mathrm{d}^{-1}$, is also used [Dymaczewski et al., 1997]

\section{MATERIAL AND METHODS}

\section{Dairy WWTP characteristic}

The research was carried out in a wastewater treatment plant of dairy cooperative Bielmlek in Bielsk Podlaski, Poland. The dairy plant specializes in the production of cheese, butter, powdered milk and powdered whey. The designed hydraulic capacity of their dairy WWTP is $750 \mathrm{~m}^{3} \cdot \mathrm{d}^{-1}$, while the maximum is $1200 \mathrm{~m}^{3} \cdot \mathrm{d}^{-1}$. Mechanical and biological blocs are capable of treating daily up to $1106 \mathrm{kgO} \cdot \mathrm{d}^{-1}, 2531 \mathrm{kgO} \cdot \mathrm{d}^{-1}, 348 \mathrm{~kg} \cdot \mathrm{d}^{-1}$, $90 \mathrm{kgN} \cdot \mathrm{d}^{-1}$ and $13,5 \mathrm{kgP} \cdot \mathrm{d}^{-1}$ of $\mathrm{BOD}_{5}, \mathrm{COD}$, TSS, TN and TP respectively. The production profile of the site determines a high concentration of or- ganic pollutants in sewage, as well as high fluctuations in the quality and quantity of wastewater [Dąbrowski \& Żyłka, 2015; Danalewich et al., 1998]. According to the data obtained in 2016, the average flow capacity was $550 \mathrm{~m}^{3} \cdot \mathrm{d}^{-1}$ (range 220-2020), the personal equivalent was on average 13500 and daily dewatered sludge production was 0.22 tons of dry mass. The average concentration of pollutants in the inflow in 2016 was 1521 (350-2650) $\mathrm{mgO}_{2} \cdot \mathrm{dm}^{-3}, 2055$ (456-4410) $\mathrm{mgO}_{2} \cdot \mathrm{dm}^{-3}, 90.1(7.2-265.0) \mathrm{mgN} \cdot \mathrm{dm}^{-3}$ and 19.5 (4.7-36.0) $\mathrm{mgP} \cdot \mathrm{dm}^{-3}$ for $\mathrm{BOD}_{5}, \mathrm{COD}, \mathrm{TN}$ and TP respectively. The primary sewage treatment is based on screening, sand removal and dissolved air flotation DAF (Fig. 1). The biological treatment is carried out in two Sequencing Batch Reactors (SBRs). Excessive sludge is mechanically dewatered and used as fertilizer. The treated wastewater is discharged to the Biała river. Figure 2 presents a scheme of Bielmlek dairy WWTP (sewage and sludge treatment). The required treatment efficiency for dairy WWTPs is determined by Water Permission [IPPC, 2015]. It specifies the maximum concentration of pollutants in the outflow as $25,125,30$ and $1 \mathrm{mg} \cdot \mathrm{dm}^{-3}$ for $\mathrm{BOD}_{5}, \mathrm{COD}, \mathrm{TN}$ and $\mathrm{TP}$, respectively.

\section{Laboratory scale installation}

In laboratory tests, the pretreated sewage from Bielmlek dairy WWTP after DAF flotation was used. A testing system designed by the GUNT company (figure 3) was applied mainly for carbon removal and nitrification. It consisted of a TF filled with fittings made of HDPE ma-

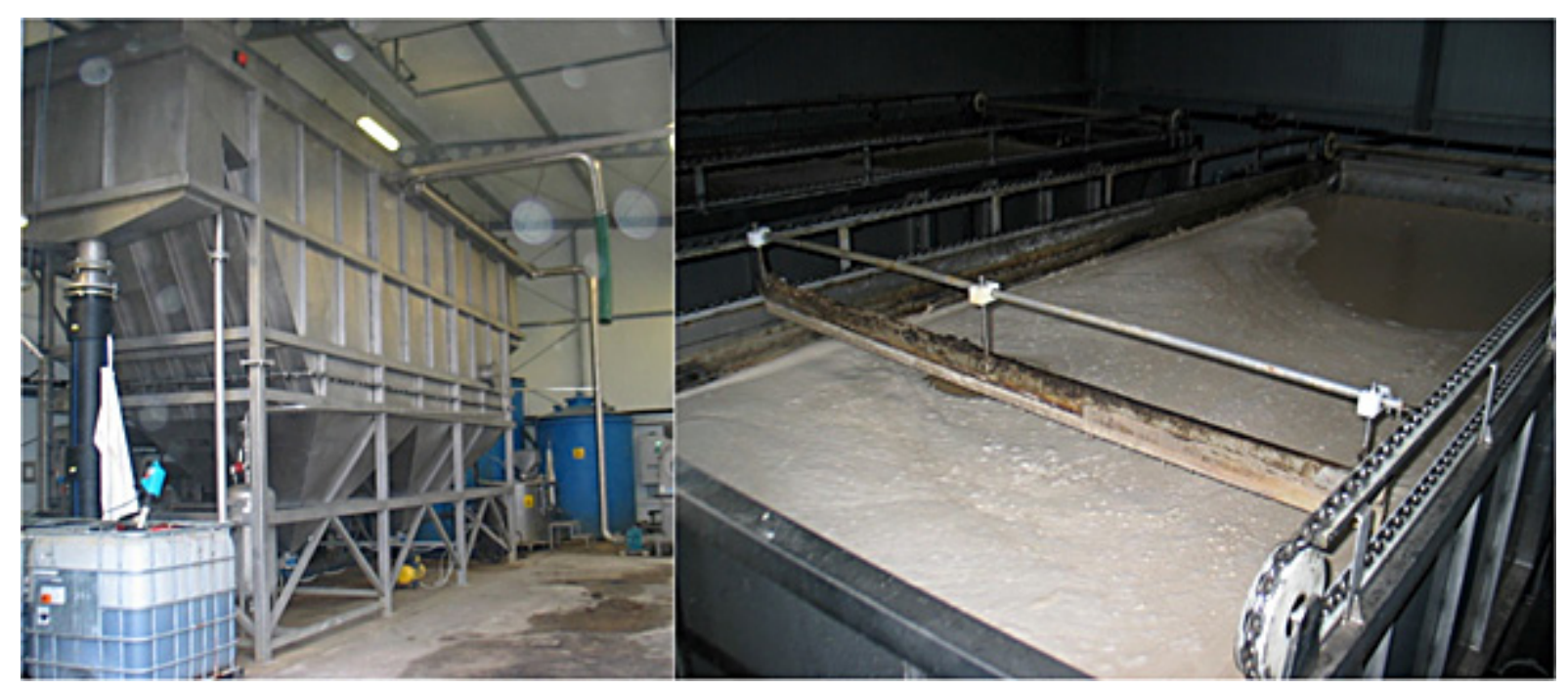

Figure 1. DAF flotation in Bielmlek WWTP 
terial. The total volume of the TF is 90 liters, while its diameter measures $340 \mathrm{~mm}$. The supplying tank has the volume of 200 liters. The carrier material (HDPE) has the specific surface of $180 \mathrm{~m}^{2} \cdot \mathrm{m}^{-3}$. The rotary distributor allows an even supply of the bed (sprinkling), while the aeration vents located below a fixed bed supply the biofilm process with oxygen. The CE 701 model is also equipped with a collecting tank and recirculation pumps. A secondary clarifier and aeration compressor are used only during the startup of the biofilm process.

\section{Sampling, measuring methods and startup of biofilm process}

The efficiency tests of DAF flotation in Bielmlek dairy WWTP were carried out in October and November 2017 (ten series). The laboratory scale part of the research with the TF was conducted in November 2017 (12 series with $0.44 \mathrm{~m}^{3} \cdot \mathrm{m}^{-2} \cdot \mathrm{d}^{-1}$ hydraulic load, with and without recirculation). During the operation, $100 \%$ recirculation was applied to achieve the results allowing for reaching the parameters required for the quality of treated sewage in Bielmlek WWTP [IPPC, 2015]. The air temperature during the laboratory scale experiment was stable and varied from $16^{\circ} \mathrm{C}$ to $18^{\circ} \mathrm{C}$. The basic physical and chemical analyses were performed, including: biochemical oxygen demand $\mathrm{BOD}_{5}$, chemical oxygen demand COD, total organic carbon TOC, total Kjeldahl nitrogen TKN, ammonia nitrogen $\mathrm{N}-\mathrm{NH}_{4}^{+}$, nitrate nitrogen $\mathrm{N}_{-} \mathrm{NO}_{3}^{-}$, nitrite nitrogen $\mathrm{N}^{-\mathrm{NO}_{2}}{ }^{-}$and total phosphorus TP. The parameters of dairy sewage supplying the installation were used to calculate the load of the TF. Deter-

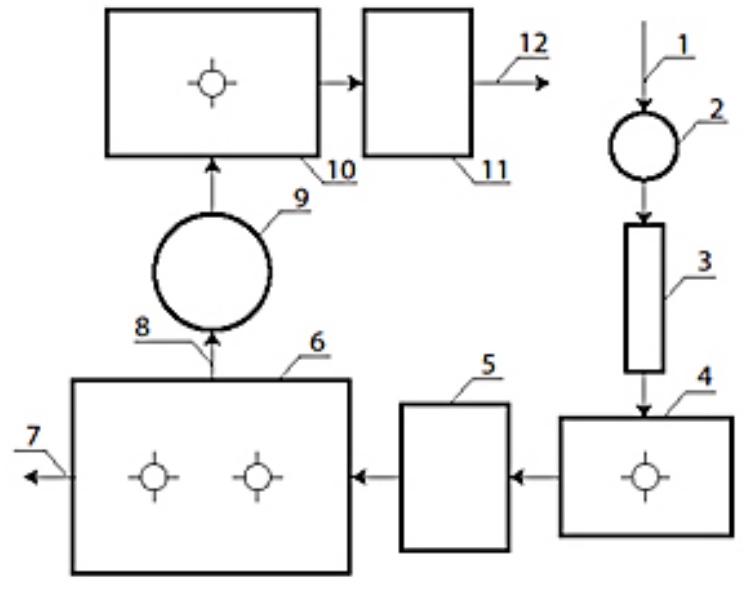

Figure 2. Flow diagram of Bielmlek dairy WWTP: 1. Raw dairy sewage, 2. Screen, 3. Grit chamber, 4. Buffer tank, 5. DAF flotator, 6. SBRs, 7. Treated sewage discharged to receiver (Biała river), 8. Excess sludge, 9. Thickener, 10. Aerobic sewage sludge stabilization chamber, 11. Dewatering press, 12. Sludge for disposal

minations were conducted in a certified laboratory, in accordance with the procedures set out in the Regulation of the Environmental Protection Minister from $18^{\text {th }}$ November 2014 and in line with the American Public Health Association [APHA, 2005].

In accordance the instruction, the start-up of the TF model lasted eleven weeks. At the beginning, the TF was supplied with activated sludge using aeration to obtain biofilm. Then, supplying the research installation with dairy sewage began. The examination of the biofilm structure (its content) in a BUT laboratory confirmed the proper functioning of the bed. Figure 4 presents microorganisms in the biofilm obtained during the startup.

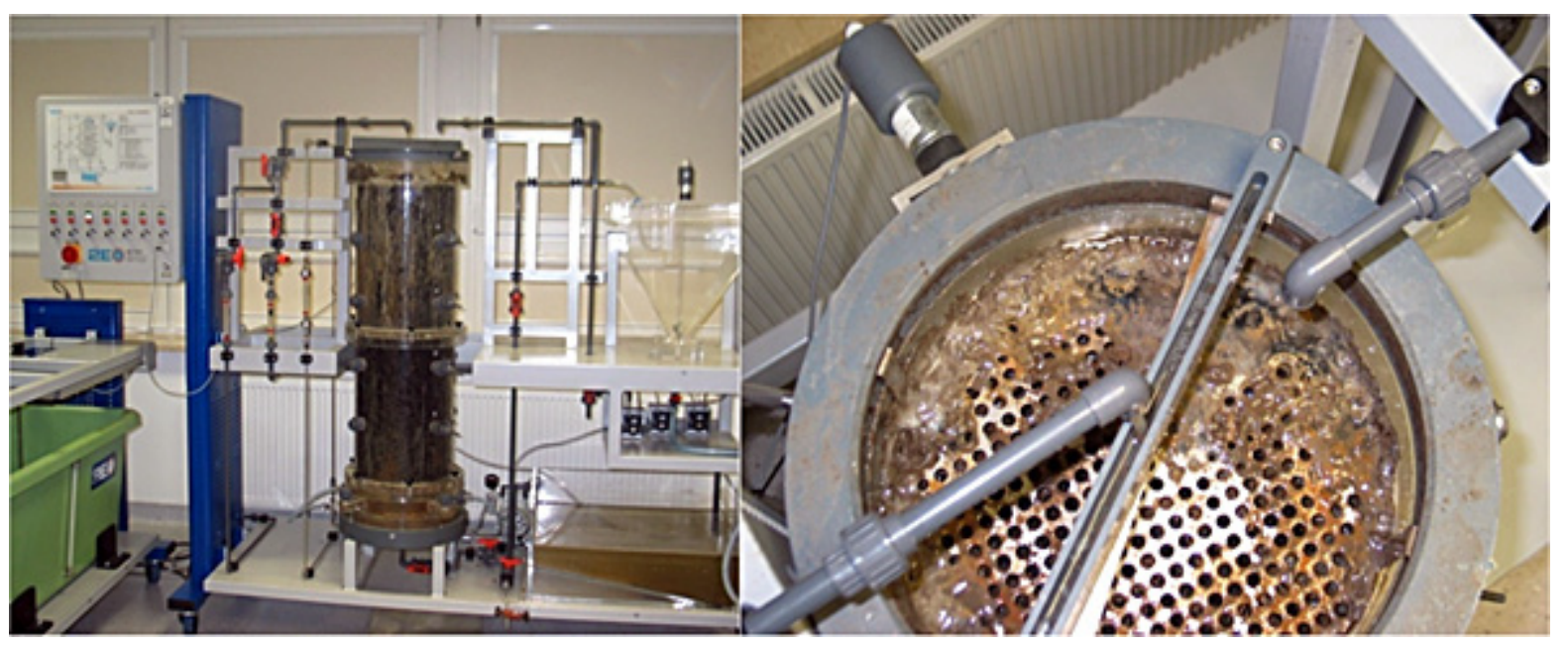

Figure 3. Research installation with main elements during operation (Nov 2017) 


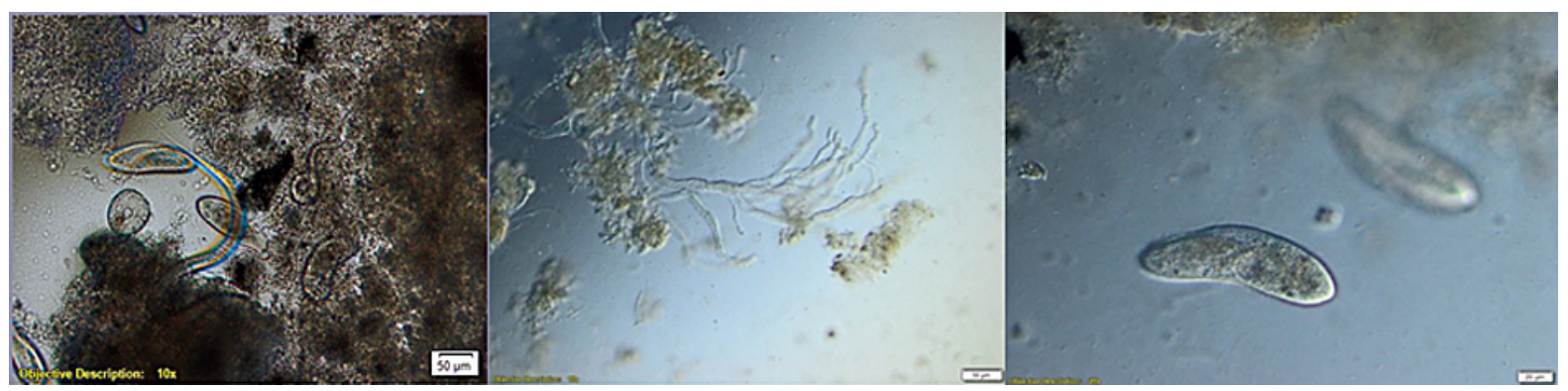

Figure 4. Biocenosis of biofilm, research installation after the startup [Butarewicz]

\section{RESULTS AND DISCUSSION}

\section{Efficiency of DAF treatment}

The DAF device proved to be very effective in removing the pollution load from the dairy wastewater. During the research period, the mean value of percentage removal was $59.3 \%, 49.0 \%$, $39.8 \%$, and $80 \%$ for $\mathrm{BOD}_{5}, \mathrm{COD}, \mathrm{TN}$ and $\mathrm{TP}$, respectively (Fig. 5). It corresponds to the literature data. Passeggi et al. (2012) obtained 20\% efficiency in terms of COD removal, while Rusten et al. (1993) examined the influence of different coagulants concentration and obtained $60 \%$ efficiency. Organic pollutants expressed as BOD and $\mathrm{COD}$ in the influent ranged from $850 \mathrm{mgO} \cdot \mathrm{dm}^{-3}$ to $1650 \mathrm{mgO} \cdot \mathrm{dm}^{-3}$ and from $1215 \mathrm{mgO}_{2} \cdot \mathrm{dm}^{-3}$ to $2465 \mathrm{mgO}_{2} \cdot \mathrm{dm}^{-3}$ respectively, while in the effluent, they ranged from $410 \mathrm{mgO} \cdot \mathrm{dm}^{-3}$ to 660 $\mathrm{mgO}_{2} \cdot \mathrm{dm}^{-3}$, and from $780 \mathrm{mgO}{ }_{2} \cdot \mathrm{dm}^{-3}$ to 930 $\mathrm{mgO}_{2} \cdot \mathrm{dm}^{-3}$, respectively. Nutrients, expressed as total nitrogen and total phosphorus in the influent ranged from $52 \mathrm{mgN} \cdot \mathrm{dm}^{-3}$ to $152 \mathrm{mgN} \cdot \mathrm{dm}^{-3}$ and from $13,6 \mathrm{mgP} \cdot \mathrm{dm}^{-3 \mathrm{n}}$ to $25.4 \mathrm{mgP} \cdot \mathrm{dm}^{-3}$ respectively, while in the effluent they ranged from 24 $\mathrm{mgN} \cdot \mathrm{dm}^{-3}$ to $59 \mathrm{mgN} \cdot \mathrm{dm}^{-3}$ and from $1.0 \mathrm{mgP} \cdot \mathrm{dm}^{-3}$

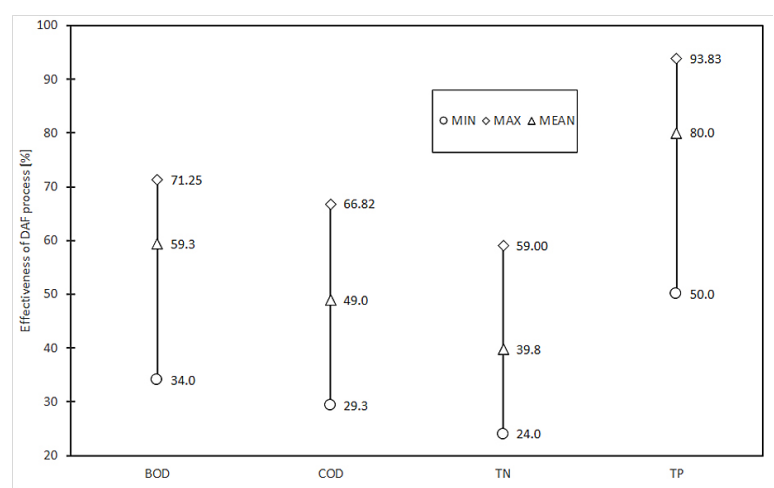

Figure 5. Pollutants removing effectiveness of the DAF process in Bielmlek dairy WWTP during the research period to $6,8 \mathrm{mgP} \cdot \mathrm{dm}^{-3}$ respectively (table 1 ). Babatola et al. (2011) studied the efficiency of DAF device for dairy sewage and received the removal rates equal to $66.09 \%, 65.89 \%$ and $94.49 \%$ for BOD, $\mathrm{COD}$ and TN respectively. The DAF system is also very effective in removing fats and oils from wastewater. The research carried by Al-Shamrani et al. (2002) showed that properly adjusted mixing and flocculation times can lead to significant oil separation, achieving more than 99\% removal.

\section{Efficiency of TF treatment}

Table 2 presents the dairy wastewater characteristic after the DAF process (average and SD) which supplied the TF during the research period. It also presents the results of treatment during the operation with and without recirculation. The average chemical composition of the dairy wastewater feeding the TF varied from 460 to $540 \mathrm{mgO} \cdot \mathrm{dm}^{-3}$ for $\mathrm{BOD}_{5}, 740-810 \mathrm{mgO} \cdot \mathrm{dm}^{-3}$ for COD, $190-240 \mathrm{mg} \cdot \mathrm{dm}^{-3}$ for TOC, 5-9.4 $\mathrm{mgN}-\mathrm{NH}_{4}^{+} \cdot \mathrm{dm}^{-3}$ for ammonia nitrogen and $1.4-3$ $\mathrm{mgP} \cdot \mathrm{dm}^{-3}$ for total phosphorus. The content of sewage before the flotation process (table 1) did not differ from the typical sewage content in broad production range (milk, cheese, powder milk). The sewage content after the DAF process is very individual and depends mainly on the amount of chemicals used in this process [Dąbrowski, 2011, Dąbrowski et al. 2016.] It was observed that during the experiment without treated sewage recirculation, sewage parameters significantly exceeded the permitted emission standards for Bielmlek WWTP [IPPC, 2015]. Only the phosphorous concentration was below the permitted value.

The load indicator during treatment without recirculation was calculated using the average values of $\mathrm{BOD}_{5}$, hydraulic flow and $\mathrm{TF}$ volume. It reached $0.22 \mathrm{kgBOD}_{5} \cdot \mathrm{m}^{-3} \cdot \mathrm{d}^{-1}$ and 0.25 with $100 \%$ recirculation. The treatment efficiency of the TF with recirculation was $95.2 \%$ for BOD and $85.5 \%$ 
Table 1. Concentration of pollutants before and after the DAF process. Mean values \pm standard deviation.

\begin{tabular}{|c|c|c|c|c|c|c|c|}
\hline \multicolumn{2}{|c|}{$\mathrm{BOD}_{5}$} & \multicolumn{2}{c|}{$\mathrm{COD}$} & \multicolumn{2}{c|}{$\mathrm{N}$-tot. } & \multicolumn{2}{c|}{ P-tot. } \\
\hline \multicolumn{2}{|c|}{$\mathrm{mgO}_{2} \cdot \mathrm{dm}^{-3}$} & \multicolumn{2}{c|}{$\mathrm{mgO}_{2} \cdot \mathrm{dm}^{-3}$} & \multicolumn{2}{c|}{$\mathrm{mgN} \cdot \mathrm{dm}^{-3}$} & \multicolumn{2}{c|}{$\mathrm{mgP} \cdot \mathrm{dm}^{-3}$} \\
\hline $\mathrm{IN}$ & OUT & $\mathrm{IN}$ & OUT & INL & OUT & IN & OUT \\
\hline $1336 \pm 281.1$ & $518 \pm 70.7$ & $1735 \pm 374.3$ & $843 \pm 57.8$ & $84 \pm 29.9$ & $40 \pm 12.4$ & $20.3 \pm 4.5$ & $3.8 \pm 1.5$ \\
\hline
\end{tabular}

Table 2. Wastewater parameters during trickling filter treating. Mean value \pm standard deviation

\begin{tabular}{|c|c|c|c|c|}
\hline Item & Unit & Inlet & Outlet - no recirculation & Outlet $-100 \%$ recirculation \\
\hline $\mathrm{BOD}_{5}$ & $\mathrm{mgO}_{2} \cdot \mathrm{dm}^{-3}$ & $505.5 \pm 26.71$ & $63.7 \pm 7.73$ & $24.2 \pm 2.10$ \\
\hline COD & $\mathrm{mgO}_{2} \cdot \mathrm{dm}^{-3}$ & $782 \pm 22.39$ & $169.3 \pm 12.53$ & $113.6 \pm 5.83$ \\
\hline TOC & $\mathrm{mg} \cdot \mathrm{dm}^{-3}$ & $212.5 \pm 18.06$ & $32.6 \pm 4.53$ & $11.3 \pm 1.64$ \\
\hline TKN & $\mathrm{mgN} \cdot \mathrm{dm}^{-3}$ & $48 \pm 4.83$ & $35.8 \pm 2.15$ & $25.2 \pm 2.86$ \\
\hline $\mathrm{N}-\mathrm{NH}_{4}^{+}$ & $\mathrm{mgN}-\mathrm{NH}_{4}^{+} \cdot \mathrm{dm}^{-3}$ & $6.89 \pm 1.53$ & $1.48 \pm 0.51$ & $0.76 \pm 0.21$ \\
\hline $\mathrm{N}-\mathrm{NO}_{3}^{-}$ & $\mathrm{mgN}-\mathrm{NO}_{3}^{-\cdot} \cdot \mathrm{dm}^{-3}$ & $1.54 \pm 0.61$ & $13.03 \pm 1.89$ & $14.04 \pm 2.44$ \\
\hline TP & $\mathrm{mgP} \cdot \mathrm{dm}^{-3}$ & $2.32 \pm 0.60$ & $1.66 \pm 0.43$ & $1.33 \pm 0.40$ \\
\hline
\end{tabular}

for COD. In the sewage treated with recirculation, the average BOD was $24.2 \mathrm{mgO}_{2} \cdot \mathrm{dm}^{-3}$ and COD $113.6 \mathrm{mgO}_{2} \cdot \mathrm{dm}^{-3}$. Such parameters met the demands set for Bielmlek WWTP $\left(\mathrm{BOD}_{5}, \mathrm{COD}, \mathrm{P}\right.$ Total). Recirculation of the treated sewage caused a decrease in the $\mathrm{BOD}_{5}$ value in the influent from 505.5 to $283.7 \mathrm{mgO}_{2} \cdot \mathrm{dm}^{-3}$. In the case of COD, recirculation caused its decrease in the TF influent from 782.0 to $475.6 \mathrm{mgO}_{2} \cdot \mathrm{dm}^{-3}$. Reaching a high level of removing organic substance during the TF treatment was possible due to a very low bed load, as well as high temperature during the tests. In the research conducted by Rodziewicz et al. (2014) on an anaerobic disc batch reactor, the value of COD decreased from 530.5 to 74.0 $\mathrm{mgO}_{2} \cdot \mathrm{dm}^{-3}$ during the synthetic sewage primary treatment with the use of four stage RBC. The TFs operating at low load are dedicated to conduct the nitrification process [Daigger \& Boltz, 2011]. Increased effectiveness in removing the organic substance measured by $\mathrm{BOD}_{5}$ and $\mathrm{COD}$ values can be achieved by, for example, using modified media for biofilm growing [ŁobosMojsa et al., 2016]. In the authors' own research, a very low concentration of ammonia nitrogen in the dairy sewage after the DAF process was observed. The concentration of ammonia nitrogen was on average $6.89 \mathrm{mgN}-\mathrm{NH}_{4}^{+} \cdot \mathrm{dm}^{-3}$ (table 2), while the concentration of TKN was on average $48.0 \mathrm{mgN} \cdot \mathrm{dm}^{-3}$. Finally, $88.8 \%$ decrease of ammonia nitrogen and nearly $47.0 \%$ of TKN (with recirculation) were achieved. The concentration of nitrates raised from $1.54 \mathrm{mgN}^{-\mathrm{NO}_{3}}{ }^{-} \cdot \mathrm{dm}^{-3}$ to $13.03 \mathrm{mgN}-\mathrm{NO}_{3}^{-} \cdot \mathrm{dm}^{-3}$ and $14.04 \mathrm{mgN}-\mathrm{NO}_{3} \cdot \mathrm{dm}^{-3}$ in the experiments with and without recirculation, respectively. The calculated value of total nitrogen in the treated sewage, on the basis of the average concentration of Kjeldahl nitrogen, nitrates and nitrites, equaled $48.8 \mathrm{mgN} \cdot \mathrm{dm}^{-3}$ for the treatment without recirculation and $39.0 \mathrm{mgN} \cdot \mathrm{dm}^{-3}$ for

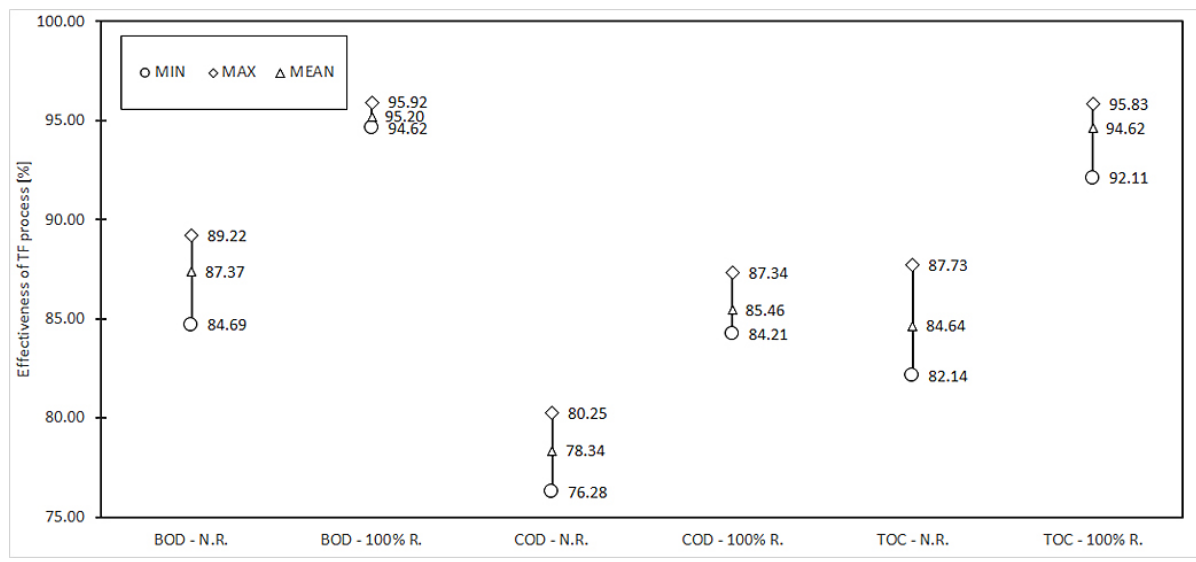

Figure 6. Effectiveness of the TF process. Parameters BOD, COD and TOC; N.R. - no recirculation applied (N.R.), $100 \%$ R. $-100 \%$ recirculation applied 


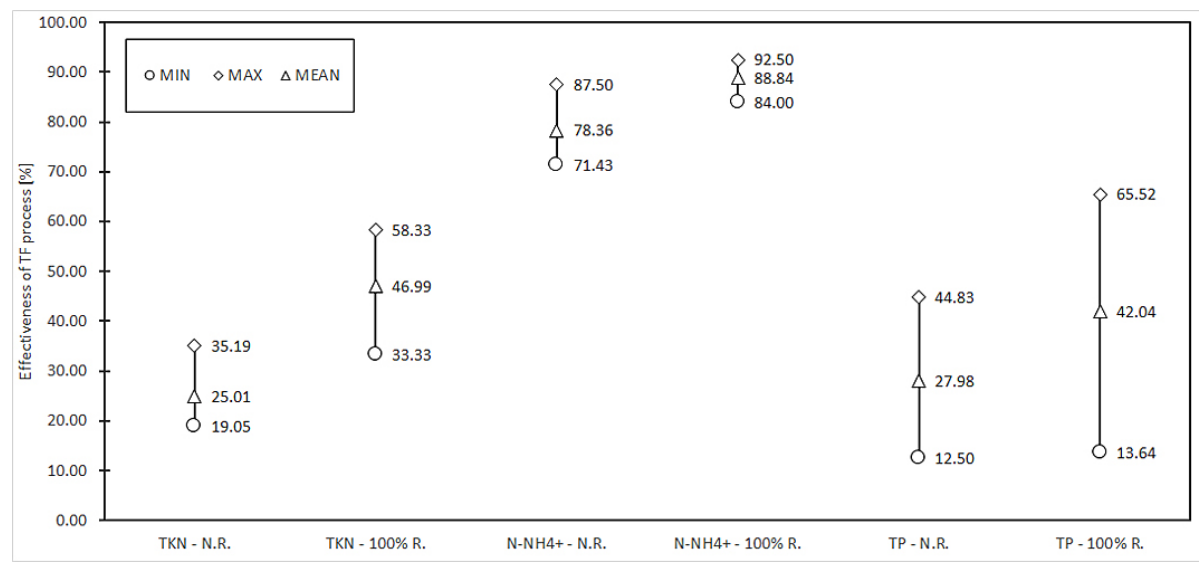

Figure 7. Effectiveness of the TF process. Parameters TKN, N-NH ${ }_{4}^{+}$and TP; N.R. - no recirculation applied, $100 \%$ R. $-100 \%$ recirculation applied

the treatment with recirculation. The concentration of nitrites was below $0.2 \mathrm{mg} \mathrm{N}-\mathrm{NO}_{2} \cdot \mathrm{dm}^{-3}$ in raw sewage and after treatment with and without recirculation. The conditions of conducting the process ensured high level of nitrification typical for TFs [Post \& Medlock, 2002]. Intensification of the nitrogen removal through the process of biological denitrification requires applying multi-layered beds with modified filling or increasing recirculation level [Kanda et al., 2016; Łobos-Moysa et al., 2016].

\section{CONCLUSIONS}

Currently, the DAF process is commonly used in the food industry WWTPs, especially with meat and dairy production wastewater. Its application can decrease the load of organic matter, phosphorus and nitrogen in raw wastewater. It substantially decreases the load of the biological treatment part of WWTPs. During the research concerning treating dairy wastewater after DAF process with $\mathrm{TF}$ technology, it was proven that it is possible to achieve high efficiency of treatment. The parameters after treatment with low load TF allowed to discharge sewage to the receiver (BOD, COD and TP). The average efficiency of treatment was up to $95.9 \%$ for BOD and up to $87.3 \%$ for COD. The issue of high efficiency phosphorus removal was solved during the DAF treatment. During the authors' own research, the concentration of TP decreased from 20.3 to $3.8 \mathrm{mgP} \cdot \mathrm{dm}^{-3}$ with DAF and reached $1.33 \mathrm{mgP} \cdot \mathrm{dm}^{-3}$ after TF treatment, on average. The efficiency of the chemical phosphorus removal depends mainly on the amount of chemicals used during its precipitation. It confirms the possibility of changing the activated sludge into TF technology, especially in small dairy plants. The primary advantage of this solution is a lack of excess sludge and lower consumption of energy. Further research will be conducted to determine the influence of temperature on the possibility of high efficiency treatment and the possibility of intensifying the removal of total nitrogen.

\section{Acknowledgements}

The study was conducted as a research project MB/WBIIS/17/2017 at the Faculty of Civil and Environmental Engineering of Bialystok University of Technology and financed by Ministry of Science and Higher Education of Poland. Scientific and technical cooperation agreement between BUT and Bielmlek allowed for conducting the research.

\section{REFERENCES}

1. Al-Shamrani A. A., James A., Xiao H. 2002. Destabilisation of oil-water emulsions and separation bydissolved air flotation. Water Research, 36: 1503-1512.

2. American Public Health Association (APHA). 2005. Standard Methods for Examination of Water and Wastewater. 21st edition. American Public Health Association. Washington

3. Babatola J. O., Oladepo K. T., Lukman S., Olarinoye N. O., Oke I. A. 2011. Failure Analysis of a Dissolved Air Flotation Treatment Plant in a Dairy Industry. Journal of Failure Analysis and Prevention. 11: 110-122.

4. Daigger G. T., Boltz J. P. 2011. Trickling Filter and Trickling Filter-Suspended Growth Process Design 
and Operation: A State of Art Review. Water Environmental Research. 83(5), 388-404.

5. Danalewich J. R., Papagiannis T. G., Belyea R. L., Tumbleson, M. E., Raskina L. 1998. Characterization of dairy waste streams, current treatment practices, and potential for biological nutrient removal. Water Research. 32(12), 3555-3568.

6. Dąbrowski W. 2011. Determination of pollutants concentration changes during dairy

7. wastewater treatment in Mlekovita Wysokie Mazowieckie. Ecological Engineering. 24, 236-243 (In Polish).

8. Dąbrowski W., Żyłka R., Rynkiewicz M. 2016. Evaluation of energy consumption in agro-industrial wastewater treatment plant. Journal of Ecological Engineering. 17: 73-78.

9. Dąbrowski W., Żyłka R. 2015. Evaluation of energy consumption in dairy WWTP Bielmlek Bielsk Podlaski. Ecological Engineering. 43, 68 - 74 (In Polish).

10. Godoy-Olmos S., Martinez -Lloren S., TomasVidal A., Jover-Cerda M. 2016. Influence of filter medium type, temperature and ammonia production on nitrifying trickling filters performance. Journal of Environmental Chemical Engineering. 4, 328-340.

11. Gogina E., Yantsen O. 2015. Research of biofilter feed properties. International Journal of Applied Engineering Research. 10(24), 44070-44074.

12. Habte Lemji H., Eckstädt H. 2013. A pilot scale trickling filter with pebble gravel as media and its performance to remove chemical oxygen demand from synthetic brewery wastewater. Journal of Zhejiang University - SCIENCE B (Biomedicine \& Biotechnology). 14(10), 924-933,

13. Henrich C. D., Marggraff M. 2013. Energy-efficient Wastewater Reuse - The Renaissance of Trickling Filter Technology. Proc. 9th International Conference on Water Reuse, 27-31.

14. Henrich C. D. 2014. German research underway on trickling filter practices. World Water - Wastewater Treatment. 9-10/2014, 37-38.

15. Integrated Pollution Prevention and Control (IPPC) Permission for Bielmlek Dairy Cooperative WWTP. 2015. (In Polish).

16. Kanda R., Kishimoto N., Hinobayashi J., Hashimoto T. 2016. Effects of recirculation rate of nitri- fied liquor and temperature on biological nitrification-denitrification process using a trickling filter. Water and Environment Journal. 30, 190-196.

17. Łobos-Moysa E., Bod M., Śliwa A. 2016. Influence of modified porous aggregates on the efficiency of treatment by trickling filter systems. Proceedings of ECOpole. 10(2), 693-698. (In Polish)

18. Tchobanoglous, G. 1997. Wastewater Engineering: Treatment, Disposal and Reuse, 2nd edition, Mc Graw Hill, New York

19. Obarska-Pempkowiak H., Gajewska M., Wojciechowska E. 2010. Wetland treatment of water and wastewater. PWN Publishing, Warsaw (In Polish).

20. Dymaczewski Z., Oleszkiewicz J. A., Sozański M. 1997. Wastewater treatment plant exploiter's guide. PZiTS, Poznań (In Polish).

21. Passeggi M., López I., Borzacconi L. 2012. Modified UASB reactor for dairy industry wastewater: performance indicators and comparison with the traditional approach. Journal of Cleaner Production. 26, 90-94.

22. Post T., Medlock J. 2002. Wastewater Technology Fact Sheet Tricking Filters, EPA

23. Regulations of the Minister of Environment from $5^{\text {th }}$ of November 1991 on conditions to be met for disposal of treated sewage into water and soil (Dz. U. 116, no. 503). (In Polish).

24. Regulations of the Minister of Environment from $18^{\text {th }}$ of November 2014 on conditions to be met for disposal of treated sewage into water and soil and concerning substances harmful to the environment (Dz.U. 2014. no. 1800). (In Polish).

25. Rodziewicz J., Janczukowicz W., Mielcarek A., Filipkowska U., Kłodowska I., Ostrowska K., Duchniewicz S. (2014). Anaerobic rotating disc batch reactor nutrient removal process enhanced by volatile fatty acid adsorption. Environmental Technology. 36(8), 953-958.

26. Rusten B., Lundar A., Eide O., Ødegaard H. 1993. Chemical Pretreatment of Dairy Wastewater. Water Science and Technology. 28(2): 67-76.

27. U.S Environmental Protection Agency (EPA). 2000. Wastewater Technology Fact Sheet - Trickling filters. Office of Water, Washington D.C. 